\title{
Longitudinal distribution of the ichthyofauna in a tributary of Tietê River with sources on the Basaltic Cuestas of São Paulo, Southeastern Brazil
}

\author{
Rodrigo Torres Cardoso ${ }^{1,3}$, Alexandre Kannebley de Oliveira ${ }^{2}$ \& Julio Cesar Garavello ${ }^{1}$ \\ ${ }^{1}$ Universidade Federal de São Carlos, Departamento de Ecologia e Biologia Evolutiva, Laboratório de \\ Ictiologia Sistemática, Rodovia Washington Luis Km 235, 676, São Carlos, SP, Brazil. \\ ${ }^{2}$ Universidade Federal de São Carlos, Departamento de Ciências Ambientais, Rod. Washington Luis Km \\ 235, 676, São Carlos, SP, Brazil. \\ ${ }^{3}$ Corresponding author: Rodrigo Torres Cardoso,e-mail: rodrigotc_bio@yahoo.com.br
}

CARDOSO, R.T., OLIVEIRA, A.K., GARAVELLO, J.C. Longitudinal distribution of the ichthyofauna in a tributary of Tietê River with sources on the Basaltic Cuestas of São Paulo, Southeastern Brazil. Biota Neotropica. 16(2): e20150005. http://dx.doi.org/10.1590/1676-0611-BN-2015-0005

\begin{abstract}
This work aimed to study the composition and distribution of fish species at four sites along Cabeça River, an affluent of Corumbataí River, tributary of Tietê River, intending to better understand the influence of local geomorphology on the occurrence of the species along the river. Using gill nets, trawl net, cast net and sieves, five samples were taken from each site every two months. These data were analyzed from constancy of occurrence, similarity index of Jaccard, rarefaction analysis and descriptive statistical analysis of richness. 4,532 fish individuals belonging to six different orders, 17 families and 65 species were captured. Differences in composition, richness (diversity), abundance and frequency were observed at these sites along the river. The sample site near the mouth of Cabeça River, was richer (49 species) and more abundant than the other three upstream sites, which showed fewer species and equivalent amounts each other (between 22 and 29 species). Moreover, this downstream site had the highest percentage of accessory species, whereas the other samples had a greater number of constant species. Cluster analysis from the Jaccard similarity showed that each site had distinct species composition. Cabeça River basin drains a rugged terrain in the state of São Paulo, between the Basaltic Cuestas and Peripheral Depression geomorphologic provinces. In this scenario, waterfalls and rapids influence the distribution, composition and richness of fish species.
\end{abstract}

Keywords: Neotropical fish, upper Paraná River, richness of species, composition, waterfalls.

CARDOSO, R.T., OLIVEIRA, A.K., GARAVELLO, J.C. Distribuição longitudinal da ictiofauna de um tributário do Rio Tietê com nascentes nas Cuestas Basalticas do Estado de São Paulo, Sudeste do Brasil. Biota Neotropica. 16(2): e20150005. http://dx.doi.org/10.1590/1676-0611-BN-2015-0005

Resumo: Objetivou-se com este trabalho estudar a composição e distribuição das espécies de peixes em quatro locais ao longo do Rio Cabeça, afluente do Rio Corumbataí, tributário do Rio Tietê, visando uma melhor compreensão das influencias da geomorfologia local sobre a ocorrência das espécies ao longo do rio. Usando redes de emalhar, rede de arrasto, tarrafa e peneiras, foram realizadas cinco coletas em cada ponto, uma a cada dois meses. Os dados foram analisados utilizando-se constância de ocorrência, índice de similaridade de Jaccard, análise de rarefação e uma análise estatística descritiva de riqueza. Foram coletados 4.532 indivíduos de peixes pertencentes a seis ordens, 17 famílias e 65 espécies. Diferenças na composição, riqueza (diversidade), abundância e freqüência foram observadas nos pontos ao longo do rio. O ponto quatro, perto da foz do Rio Cabeça, apresentou maior riqueza (49 espécies) e maior abundancia, e os outros três pontos apresentaram valores menores e mais próximos entre si (entre 22 e 29 espécies). Além disso, o ponto quatro teve a maior porcentagem de espécies acessórias em comparação aos outros pontos, que apresentaram maior número de espécies constantes. A análise de agrupamento a partir da similaridade de Jaccard mostrou que cada ponto teve composição de espécies diferenciada em relação aos demais. A bacia do Rio Cabeça drena uma área caracterizada por relevo acidentado no interior do estado de São Paulo, na região de transição entre as províncias geomorfológicas Cuestas Basálticas e Depressão Periférica. Nesse cenário, cachoeiras e corredeiras ao longo de seu curso interferem na distribuição, composição e riqueza das espécies de peixes.

Palavras-chave: Peixes neotropicais, Alto Rio Paraná, Riqueza de espécies, composição, cachoeiras. 


\section{Introduction}

The Tietê River rises in the Planalto Atlântico geomorphologic province, Serra do Mar region, and drains toward interior São Paulo State, crossing other provinces and flowing to the Paraná River in the border with Mato Grosso do Sul state. In its middle course, at the Barra Bonita reservoir region, the Tietê River receives waters from the Piracicaba River, from which the Corumbataí River is an affluent. Numerous sources of Corumbataí River and part of its tributaries, such as Passa Cinco and Cabeça rivers are at the top of the Cuestas Basálticas geomorphologic province (Tavares et al., 2007), and these small rivers flow toward the geomorphologic province called Depressão Periférica, a region that lies between the Precambrian flanges of Planalto Atlântico and escarpment edges of the Cuestas Basálticas western plateau. In the Corumbataí drainage, rivers and streams flow through a rugged terrain whose waterfalls and rapids influence the distribution of fish species. Bennemann et al. (1995), Casatti (2005) e Oliveira \& Garavello (2003) found that the rivers of the upper Parana River basin regularly have a natural tendency to increase in species richness from source toward the river mouth.

The river continuum concept of Vannote et al. (1980) states that features such as diversity, primary productivity, biotic relationships, and the relative importance of allochthonous material change in predictable ways over the course of a river. However, changes in the river channel may affect the characteristics of "continuity", for example: occurrence of rapids and falls that may restrict the movement of fish and influence the distribution of species in different portions of the drainage. Thus, such natural barriers may generate patterns of discontinuity in the composition and distribution of ichthyofauna (Balon \& Stewart, 1983).

The Cabeça River, main tributary of the Passa Cinco River, has an irregular relief with not only rapids but also large waterfalls, consequently hampering the passage of fishes from downstream to upstream. Thus, this physical feature of river drainage may promote a fish distribution different from the expected for rivers in plane areas, where species richness and composition may change gradually toward the mouth. So, an inventory of fish species is presented at different sites of the drainage of the Cabeça River aiming to evaluate their longitudinal distribution, and how the local geomorphology may act on the fish communities.

\section{Material and Methods}

\section{Area of study}

The headwaters of Cabeça River are located at 740 meters of altitude, in Itirapina municipality, São Paulo State, southeastern Brazil. It is a small river of the Tietê River system that flows $28 \mathrm{~km}$ from source to mouth on Passa Cinco River, at an altitude of 520 meters. It belongs to Corumbataí River basin in a drainage area of $211 \mathrm{~km}^{2}$, according Cetra \& Petrere (2006).

From maps prepared by IBGE, satellite images (Google Earth 2010) and travels for recognition, we choose four sample sites, each one with 200 meters long. Site 1 is the closest to the spring; site 2 is in the midst and sites 3 and 4 are near the mouth with the Passa Cinco River, close to each other, but separated by Altarugio Waterfall. They were purposely chosen to study

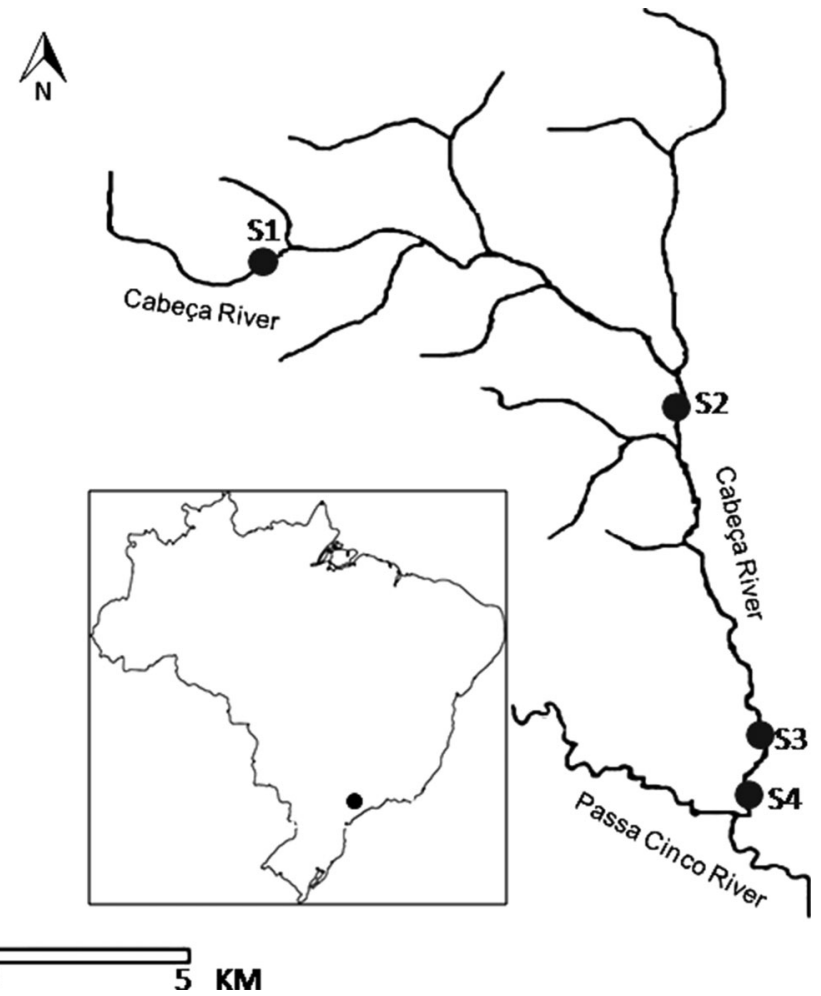

Figure 1. Drainage of the Cabeça River showing the location of the four sampling sites. Scale map: 1:250.000 kilometers.

the influence of the waterfall in the distribution of fish populations (Figure 1).

\section{Characterization of sampling sites}

Each sampling site had been characterized from the following data: geographic coordinates (Datum SAD 69), river depth and width, water speed and riparian forest. Due to the fact of each site has 200 meters in length, its physical characteristics could vary along the riverbed. The measurements were obtained in 5 locations (one every 45 meters approximately) of each sampling site. After this procedure, averages express the characteristics of the entire reach where fish were collected.

Width and depth were measured with a tape of 30 meters and the exact depth was measured from right and left banks and the center of channel. Thus, we obtained an average for each of the five sampling locations within each stretch of 200 meters and an overall average. Water velocity was measured from the time check that a float ( $5 \mathrm{~cm}$ diameter Styrofoam ball) covered a distance of three meters. This procedure was also performed at the five locations within the 200 meters stretch of the four sample sites.

\section{Sampling and identification of ichthyofauna}

Between June 2010 and April 2011, five samplings were performed at each site. The sites 1 and 2 were sampled in June, August, October, December/2010 and February/2011 and sites 3 and 4 in September, November/2010 and January, March and April/2011. 
Fish distribution in a tributary of Tietõ River

Table 1. Environmental characterization of the four sampling sites on the Cabeça River, Corumbataí River basin.

\begin{tabular}{|c|c|c|c|c|c|}
\hline $\begin{array}{l}\text { Sample } \\
\text { Site }\end{array}$ & $\begin{array}{l}\text { Geographical } \\
\text { Coordinates } \\
\text { (UTM) }\end{array}$ & $\begin{array}{l}\text { Depth } \\
\text { (m) }\end{array}$ & $\begin{array}{c}\text { Width. } \\
\text { (m) }\end{array}$ & $\begin{array}{l}\text { Water } \\
\text { velocity } \\
(\mathbf{m} / \mathbf{s})\end{array}$ & Environmental Characteristics \\
\hline 1 & $\begin{array}{l}23 \mathrm{~K} 215774 \\
7531283\end{array}$ & 0.90 & 5.06 & 0.48 & $\begin{array}{l}\text { Narrower than other sites, comparatively deep, voluminous and fast } \\
\text { water - features of rivers that drain steeper reliefs. Little aquatic or } \\
\text { terrestrial vegetation. }\end{array}$ \\
\hline 2 & $\begin{array}{l}23 \mathrm{~K} 224851 \\
7526385\end{array}$ & 1.03 & 10.50 & 0.34 & $\begin{array}{l}\text { The same depth of site } 1 \text {, but twice the average width, more open } \\
\text { water and a few deeper pools separated by rapids. Some trees and } \\
\text { aquatic vegetation in some reaches. }\end{array}$ \\
\hline 3 & $\begin{array}{l}23 \mathrm{~K} 226563 \\
7515176\end{array}$ & 1.36 & 14.26 & 0.10 & $\begin{array}{l}\text { The widest and deepest site, slow waters, few rapids and shallow } \\
\text { reaches. Aquatic vegetation and submerged structures can be found } \\
\text { as logs and rocks and the riparian vegetation is sparse. }\end{array}$ \\
\hline 4 & $\begin{array}{l}23 \mathrm{~K} 226675 \\
7514907\end{array}$ & 0.90 & 13.72 & 0.34 & $\begin{array}{l}\text { As wide as the third site, with shallow and fast rapids. Despite of } \\
\text { abundant riparian forest, there is no aquatic vegetation. }\end{array}$ \\
\hline
\end{tabular}

Fish were collected with gill nets of 1.5 to $4.0 \mathrm{~cm}$ among adjacent nodes, trawling ( $2 \mathrm{~mm}$ mesh), cast net $(2 \mathrm{~cm}$ between nodes) and sieves ( $2 \mathrm{~mm}$ mesh). In each sampling, active collecting (trawls, cast nets and sieve) was made for a period of two hours and set of gill nets remained in the water from nightfall to sunrise. The sampled material was fixed in $10 \%$ formalin, preserved in $70 \%$ ethanol, and added to the fish collection of the Laboratório de Ictiologia Sistemática of the Departamento de Ecologia a Biologia Evolutiva (LISDEBEUFSCar).

The species identification was based on comparative material housed in LISDEBE and on specialized systematic and taxonomy bibliography. Biological classification to each species is in accord to Buckup, Menezes \& Ghazzi (2007).

\section{Data analysis}

The constancy of occurrence (C) was obtained following the expression: $\mathrm{C}=(\mathrm{p} / \mathrm{P}) \times 100$, where "p" is the number of samples in which the species was recorded, and "P" the total number of samples. The species of each site were classified according to Dajoz (1983) as: constant, if $\mathrm{C} \geq 50 \%$; accessory, if $25 \%<\mathrm{C}<50 \%$, and occasional, if $\mathrm{C} \leq 25 \%$.

Jaccard similarity index was calculated by using the expression: $\mathrm{Q}=[\mathrm{C} /(\mathrm{A}+\mathrm{B}-\mathrm{C})] \mathrm{x} 100$, available in Magurran (1991), where: "A" is the number of species in a sample; "B" the number of species from another sample and " $C$ " is the number of species common to both samples "A" and "B". From these results, a similarity dendrogram was obtained using the software PAST version 2.03.

For comparison of richness among the sampling sites we calculated the averages and standard deviation and performed a rarefaction analysis according to Krebs (1999), all using the PAST software, version 2.03.

\section{Results}

\section{Environmental features of the sampling sites}

Measurements and observations of the four sites showed the features of each site and the results are in Table 1.

\section{Characterization of ichthyofauna}

Were sampled 4,532 individuals of fish belonging to six orders, 17 families and 65 species (Table 2). Characiformes was the most abundant and most diverse: presented 35 species in seven families (Erythrinidae, Characidae, Crenuchidae, Parodontidae Curimatidae, Anostomidae and Prochilodontidae). Siluriformes, 21 species in five families (Callichthyidae, Loricariidae, Trichomycteridae, Heptapteridae and Pimelodidae). Gymnotiformes, two species in two families (Sternopygidae and Gymnotidae). Cyprinodontiformes, two species in a family (Poeciliidae). Perciformes, four species in a family (Cichlidae). And Synbranchiformes presented a single species of the family Synbranchidae.

In site 1, 408 individuals were sampled, belonging to 22 species. In site 2 , the 1218 individuals belonged to 29 species. In site 3 , the 668 individuals belonged to 25 species. In site 4 , 49 species and 1476 individuals (Table 2) were sampled.

The rarefaction analysis (Figure 2) shows that, for standard samples, site 4 is richest than sites 1,2 and 3 . For a 408 individuals sampling: site 1 had 22 species; site 2, 25 species; site 3, 23 species; and site 4, 35 species.

Regarding to constancy of species, site 1 had 15 constant species $(68.2 \%), 3$ accessory species $(13.6 \%)$ and 4 occasional species $(18.2 \%)$. In site 2, 20 species were constant $(69.0 \%)$, 4 accessory (13.8\%) and 5 occasional (17.2\%). Site 3, 12 species were constant (48\%), 8 accessory $(32 \%)$ and 5 occasional $(20 \%)$. Site 4, 19 constant species $(38.8 \%), 15$ accessory $(30.6 \%)$ and 15 occasional species $(30.6 \%)$ (Table 2$)$.

The similarity dendrogram showed different species composition in each of the sampled sites (Figure 3). Samples taken at sites 1,2 , and 3 were more similar to each other and in relation to themselves. Instead, site 4 they were less similar to themselves and relative to the other sites. The cophenetic correlation coefficient $(r=0.9484)$ showed a low degree of distortion of the dendrogram relative to the data similarity matrix.

\section{Species Distribution}

Fish species were distributed in the sample sites in the following way: Cyphocharax vanderi, only at site 1; 
Table 2. Taxonomic list of species registered in Cabeça River, number of individuals of each species $(\mathrm{N})$ and $\mathrm{CO}=$ constancy of species occurrence $(\mathrm{A}=$ accessory, $\mathrm{C}=$ constant and $\mathrm{O}=$ occasional $)$.

\begin{tabular}{|c|c|c|c|c|c|c|c|c|}
\hline & \multicolumn{2}{|c|}{ Site 1} & \multicolumn{2}{|c|}{ Site 2} & \multicolumn{2}{|c|}{ Site 3} & \multicolumn{2}{|c|}{ Site 4} \\
\hline & $\overline{\mathbf{N}}$ & $\mathrm{CO}$ & $\mathbf{N}$ & $\mathrm{CO}$ & $\mathbf{N}$ & $\mathrm{CO}$ & $\mathbf{N}$ & $\mathrm{CO}$ \\
\hline \multicolumn{9}{|l|}{ Superordem Ostariophysi } \\
\hline \multirow{2}{*}{\multicolumn{9}{|c|}{$\begin{array}{l}\text { Characiformes } \\
\text { Ervthrinidae }\end{array}$}} \\
\hline & & \multicolumn{7}{|c|}{ Erythrinidae } \\
\hline Hoplias intermedius (Günther 1864) & 2 & A & 7 & $\mathrm{C}$ & 6 & $\mathrm{C}$ & 4 & A \\
\hline Hoplias malabaricus (Bloch, 1794) & 1 & $\mathrm{O}$ & 2 & A & 1 & $\mathrm{O}$ & 2 & A \\
\hline \multirow{2}{*}{\multicolumn{9}{|c|}{$\begin{array}{l}\text { Characidae } \\
\text { incertae sedis }\end{array}$}} \\
\hline & & & & & & & & \\
\hline Astyanax altiparanae Garutti \& Britski, 2000 & 31 & $\mathrm{C}$ & 37 & $\mathrm{C}$ & 2 & A & 586 & $\mathrm{C}$ \\
\hline Astyanax cf. bockmanni Vari \& Castro, 2007 & & & 1 & $\mathrm{O}$ & 134 & $\mathrm{C}$ & 63 & $\mathrm{C}$ \\
\hline Astyanax fasciatus (Cuvier, 1819) & & & & & 7 & A & 28 & A \\
\hline Astyanax paranae Eigenmann, 1914 & 9 & A & 34 & $\mathrm{C}$ & & & & \\
\hline Bryconamericus stramineus Eigenmann, 1908 & & & & & 34 & $\mathrm{C}$ & 14 & $\mathrm{C}$ \\
\hline Bryconamericus turiuba Langeani et al., 2005 & & & & & 222 & $\mathrm{C}$ & 252 & $\mathrm{C}$ \\
\hline Hyphessobrycon anisitsi (Eigenmann, 1907) & 6 & $\mathrm{C}$ & 1 & $\mathrm{O}$ & & 1 & $\mathrm{O}$ & \\
\hline Hyphessobrycon bifasciatus Ellis, 1911 & & & 13 & $\mathrm{C}$ & 2 & A & & \\
\hline Oligosarcus pintoi Campos, 1945 & 46 & $\mathrm{C}$ & 2 & $\mathrm{O}$ & 34 & $\mathrm{C}$ & & \\
\hline Piabina argentea Reinhardt, 1867 & & & & & 71 & $\mathrm{C}$ & 12 & $\mathrm{C}$ \\
\hline Salminus brasiliensis (Cuvier, 1816) & & & & & 1 & $\mathrm{O}$ & 2 & A \\
\hline \multicolumn{9}{|l|}{ Characinae } \\
\hline Roeboides sp. & & & & & & & 18 & $\mathrm{C}$ \\
\hline \multicolumn{9}{|l|}{ Triportheinae } \\
\hline Triportheus cf. signatus (Garman, 1890) & & & & & & & 4 & A \\
\hline \multicolumn{9}{|l|}{ Serrasalminae } \\
\hline Serrasalmus maculatus Kner, 1858 & & & & & & & 1 & $\mathrm{O}$ \\
\hline \multicolumn{9}{|l|}{ Cheirodontinae } \\
\hline Odontostilbe sp. 1 & & & & & & & 42 & $\mathrm{O}$ \\
\hline Odontostilbe sp. 2 & 12 & A & 6 & A & & 12 & A & \\
\hline Serrapinnus heterodon (Eigenmann, 1915) & 25 & $\mathrm{C}$ & 48 & $\mathrm{C}$ & & 5 & A & \\
\hline Serrapinnus notomelas (Eigenmann, 1915) & 1 & $\mathrm{O}$ & 40 & $\mathrm{C}$ & 3 & A & 2 & $\mathrm{O}$ \\
\hline \multicolumn{9}{|l|}{ Aphyocharacinae } \\
\hline Aphyocharax dentatus Eigenmann e Kennedy, 1903 & & & & & & & 2 & A \\
\hline \multicolumn{9}{|l|}{ Crenuchidae } \\
\hline Characidium gomesi Travassos, 1956 & & & 47 & $\mathrm{C}$ & 3 & A & 1 & $\mathrm{O}$ \\
\hline Characidium zebra Eigenmann, 1909 & 39 & $\mathrm{C}$ & 31 & $\mathrm{C}$ & 65 & $\mathrm{C}$ & 72 & $\mathrm{C}$ \\
\hline \multicolumn{9}{|l|}{ Parodontidae } \\
\hline Apareiodon affinis (Steindachner, 1879) & & & & & 7 & A & 9 & A \\
\hline Parodon nasus Kner, 1859 & & & & & 3 & $\mathrm{C}$ & 9 & $\mathrm{C}$ \\
\hline \multicolumn{9}{|l|}{ Curimatidae } \\
\hline Cyphocharax modestus (Fernández-Yépez, 1948) & 11 & $\mathrm{C}$ & 6 & $\mathrm{C}$ & & & & \\
\hline Cyphocharax nagelii (Steindachner, 1881) & & & & & & & 50 & $\mathrm{C}$ \\
\hline Cyphocharax vanderi (Britski, 1980) & 1 & $\mathrm{O}$ & & & & & & \\
\hline Steindachnerina insculpta (Fernández-Yépez, 1948) & & & & & & & 3 & $\mathrm{C}$ \\
\hline Anostomidae & & & & & & & & \\
\hline Leporinus aff. friderici (Bloch, 1794) & & & & & & & 2 & A \\
\hline Leporinus lacustris Campos, 1945 & & & & & & & 1 & $\mathrm{O}$ \\
\hline Leporinus obtusidens (Valenciennes, 1837) & & & & & & & 2 & $\mathrm{O}$ \\
\hline Leporinus octofasciatus Steindachner, 1915 & & & & & & & 1 & $\mathrm{O}$ \\
\hline Schizodon nasutus Kner, 1858 & & & & & & & 1 & $\mathrm{O}$ \\
\hline Prochilodontidae & & & & & & & & \\
\hline Prochilodus lineatus (Valenciennes, 1836) & & & & & & & 2 & $\mathrm{O}$ \\
\hline Siluriformes & & & & & & & & \\
\hline Callichthyidae & & & & & & & & \\
\hline Corydoras aeneus (Gill, 1858) & 17 & $\mathrm{C}$ & 558 & $\mathrm{C}$ & & & & \\
\hline Corydoras flaveolus Ihering, 1911 & & & & & & & 55 & $\mathrm{C}$ \\
\hline Hoplosternum littorale (Hancock, 1828) & & & 2 & A & & & & \\
\hline
\end{tabular}


Table 2. Continued.

\begin{tabular}{|c|c|c|c|c|c|c|c|c|}
\hline & \multicolumn{2}{|c|}{ Site 1} & \multicolumn{2}{|c|}{ Site 2} & \multicolumn{2}{|c|}{ Site 3} & \multicolumn{2}{|c|}{ Site 4} \\
\hline & $\mathbf{N}$ & $\mathrm{CO}$ & $\mathbf{N}$ & $\mathrm{CO}$ & $\mathbf{N}$ & $\mathrm{CO}$ & $\mathbf{N}$ & $\mathrm{CO}$ \\
\hline \multicolumn{9}{|l|}{ Loricariidae } \\
\hline \multicolumn{9}{|l|}{ Loricariinae } \\
\hline Rineloricaria latirostris (Boulenger, 1900) & & & & & 3 & $\mathrm{C}$ & 9 & $\mathrm{C}$ \\
\hline \multicolumn{9}{|l|}{ Hypostominae } \\
\hline Hypostomus albopunctatus (Regan, 1908) & & & & & & & 12 & $\mathrm{C}$ \\
\hline Hypostomus ancistroides (Ihering, 1911) & 17 & $\mathrm{C}$ & 18 & $\mathrm{C}$ & 14 & $\mathrm{C}$ & 6 & $\mathrm{C}$ \\
\hline Hypostomus hermanni (Ihering, 1905) & & & & & & & 9 & $\mathrm{C}$ \\
\hline Hypostomus nigromaculatus (Schubart, 1964) & & & & & 3 & $\mathrm{O}$ & 7 & $\mathrm{C}$ \\
\hline Hypostomus paulinus (Ihering, 1905) & & & & & & & 28 & $\mathrm{C}$ \\
\hline Hypostomus cf. strigaticeps (Regan, 1908) & & & 26 & $\mathrm{C}$ & 13 & A & 87 & $\mathrm{C}$ \\
\hline Hypostomus sp. & & & & & & & 9 & A \\
\hline \multicolumn{9}{|l|}{ Hypoptopomatinae } \\
\hline Corumbataia cuestae Britski, 1997 & 53 & $\mathrm{C}$ & 65 & $\mathrm{C}$ & & & & \\
\hline \multicolumn{9}{|l|}{ Trichomycteridae } \\
\hline \multicolumn{9}{|l|}{ Trichomycterinae } \\
\hline Trichomycterus sp. & 14 & $\mathrm{C}$ & 12 & $\mathrm{C}$ & & & & \\
\hline \multicolumn{9}{|l|}{ Heptapteridae } \\
\hline Cetopsorhamdia iheringi Schubart e Gomes, 1959 & & & & & 1 & $\mathrm{O}$ & 3 & A \\
\hline Imparfinis cf. borodini Mees e Cala, 1989 & & & & & & & 4 & A \\
\hline Imparfinis mirini Haseman, 1911 & 5 & $\mathrm{C}$ & 40 & $\mathrm{C}$ & & & & \\
\hline Phenacorhamdia tenebrosa (Schubart 1964) & & & & & & & 1 & $\mathrm{O}$ \\
\hline Pimelodella sp. & & & & & & & 2 & A \\
\hline Rhamdia quelen (Quoy e Gaimard, 1824) & 5 & $\mathrm{C}$ & 3 & $\mathrm{C}$ & & & 15 & $\mathrm{C}$ \\
\hline \multicolumn{9}{|l|}{ Pimelodidae } \\
\hline Pimelodus maculatus Lacépède, 1803 & & & & & 2 & A & & \\
\hline Pimelodus microstoma Steindachner, 1877 & & & & & 2 & $\mathrm{O}$ & 4 & A \\
\hline \multicolumn{9}{|l|}{ Gymnotiformes } \\
\hline \multicolumn{9}{|l|}{ Sternopygidae } \\
\hline Eigenmannia sp. & & & & & & & 2 & $\mathrm{O}$ \\
\hline \multicolumn{9}{|l|}{ Gymnotidae } \\
\hline Gymnotus sp. & 16 & $\mathrm{C}$ & 9 & $\mathrm{C}$ & & & 1 & $\mathrm{O}$ \\
\hline \multicolumn{9}{|l|}{ Cyprinodontiformes } \\
\hline \multicolumn{9}{|l|}{ Poeciliidae } \\
\hline Phalloceros harpagos Lucinda, 2008 & 40 & $\mathrm{C}$ & 45 & $\mathrm{C}$ & & & & \\
\hline Poecilia reticulata Peters, 1859 & & & 68 & $\mathrm{C}$ & 11 & $\mathrm{C}$ & 2 & $\mathrm{O}$ \\
\hline \multicolumn{9}{|l|}{ Perciformes } \\
\hline \multicolumn{9}{|l|}{ Cichlidae } \\
\hline Australoheros sp. & & & 4 & A & & & & \\
\hline Geophagus brasiliensis (Quoy e Gaimard, 1824) & 56 & $\mathrm{C}$ & 88 & $\mathrm{C}$ & 24 & $\mathrm{C}$ & 17 & $\mathrm{O}$ \\
\hline Oreochromis niloticus (Linnaeus, 1758) & & & 5 & A & & & & \\
\hline Tilapia rendalli (Boulenger, 1897) & 1 & $\mathrm{O}$ & 3 & $\mathrm{O}$ & & & & \\
\hline \multicolumn{9}{|l|}{ Synbranchiformes } \\
\hline Synbranchidae & & & & & & & & \\
\hline Synbranchus marmoratus Bloch, 1795 & & & 1 & $\mathrm{O}$ & & & & \\
\hline Total of species & 22 & & 29 & & 25 & & 49 & \\
\hline Total of individuals & 408 & & 1218 & & 668 & & 1476 & \\
\hline Mean of species by sample & 15 & & 20.4 & & 13.2 & & 23.8 & \\
\hline Standard deviation & 2.12 & & 1.51 & & 3.5 & & 4.6 & \\
\hline
\end{tabular}

Hoplosternum littorale occurred only at site 2; and Pimelodus maculatus only at Site 3 . Site 4 had 21 exclusive species: Roeboides sp., Triportheus cf. signatus, Serrasalmus maculatus, Odontostilbe sp.1, Aphyocharax dentatus, Cyphocharax nagelii, Steindachnerina insculpta, Leporinus aff. friderici, Leporinus lacustris, Leporinus octofasciatus, Leporinus obtusidens, Schizodon nasutus, Prochilodus lineatus, Corydoras flaveolus,
Hypostomus albopunctatus, Hypostomus hermanni, Hypostomus paulinus, Hypostomus sp., Imparfinis cf. borodini, Phenacorhamdia tenebrosa, Pimelodella sp., and Eigenmannia sp.

Only seven species appeared at all sites: Hoplias intermedius, Hoplias malabaricus, Astyanax altiparanae, Serrapinnus notomelas, Characidium zebra, Hypostomus ancistroides and Geophagus brasiliensis. And 15 species appeared only in 


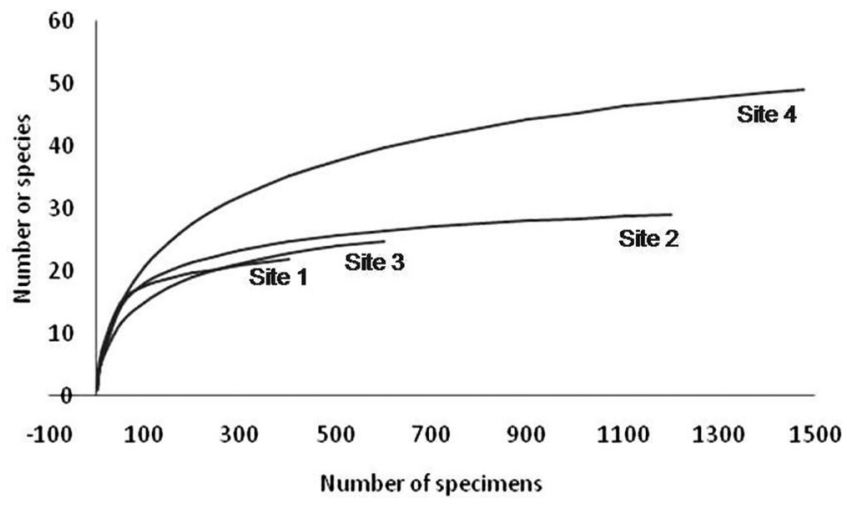

Figure 2. Rarefaction curves for the four sampling sites on the Cabeça River, Corumbataí basin.

three sites upstream of the waterfall Altarugio, namely: Astyanax paranae, Hyphessobrycon bifasciatus, Oligosarcus pintoi, Cyphocharax modestus, Cyphocharax vanderi, Corydoras aeneus, Hoplosternum littorale, Corumbataia cuestae, Trichomycterus sp, Imparfinis mirini, Pimelodus maculatus, Phalloceros harpagos, Oreochromis niloticus, Tilapia rendalli and Synbranchus marmoratus.

\section{Discussion}

Because of the rugged terrain typical of the Cuestas Basálticas relief, there are several waterfalls and rapids in the Cabeça River drainage which influence the distribution of fish species. The Altarugio Waterfall located near the confluence of the Cabeça and Passa Cinco rivers difficult upstream migration of individuals and shoals. The highest number of species recorded in the lower course of the river (site 4), but not in the nearby site 3 , attest the difficulty of fish movement upstream through the Altarugio Waterfall. The sampled site 4 contained 49 of the 65 fish species, representing $75.3 \%$ of species richness and the other three sites located upstream of the waterfall, had 42 species which together represent $64.6 \%$ of the total.

The similarities among the studied sites of Cabeça River basin reflect the differences in species composition, as well as the average and the total species richness registered in each site. Greatest similarities can be seen among the reaches to the upstream of the Altarugio fall. Considering the similarity among the samples of each site; the site 4 with $30.6 \%$ of occasional species, presented greater variation in similarity among themselves, due to a higher occurrence of different species during the sampling period. Unlike of site 4, the other three sites are more similar among themselves, perhaps by restricting fish in such sites, showed higher occurrence of constant species, where fish populations are temporally more stable. This fact was also confirmed by the rarefaction analysis in which we note that the curves of the sites 1,2 and 3 tend to stabilize with fewer samples than that of the downstream site 4, which apparently receives different species with greater intensity that upstream stretches. Similarly, Perez Jr. \& Garavello (2007) noted that of the 13 species found upstream to waterfall of Pântano River, 11 were constant $(84.6 \%)$, against a lower proportion $(43.9 \%$ of 41 species sampled downstream of the waterfall) at not isolated sites.

Langeani et al. (2005) has studied fish populations in different environments of Santa Barbara River (tributary of the
Tietê River), and stated that its proximity to major drainages could explain the higher number of rare species (occasional), usually found in larger rivers and that could temporarily explore smaller environments for feeding and reproduction. In fact, studies conducted in small rivers and streams form upper Paraná River basin attested the fact that the fish fauna in lower portions of the drainages are influenced by downstream greater rivers, as discussed by Pavanelli \& Caramaschi (1997) when studied tributaries of the Paraná River and Oliveira et al. (2009) in tributaries of the Mogi-Guaçu River.

Although this hypothesis of stability versus temporal variability should be tested in medium and long term, the following discussion reinforces that the waterfall Altarugio acts as an important factor in the structure of fish assemblages, especially in terms of composition and ichthyofauna distribution. This becomes evident by comparison of the species richness among the closely located sites 3 and 4, and the difference of 24 more species recorded downstream from the waterfall. This waterfall influence was also observed in others studies, as by Perez Jr. \& Garavello (2007), studying the Pântano River and showing large varieties of species among the sites separated by Pântano waterfall, where only 13 species out of 63 were recorded. Also, Jonck \& Aranha (2010) have studied the aquatic population of two pools, separated by a waterfall in a Atlantic Rainforest stream and have concluded that there is a strong influence of the obstacle, the waterfall, especially to the organisms that spend all their life cycle in water.

On the other hand, gentler slope rivers, as Cabaceiras Stream that were studied by Oliveira \& Garavello (2003), have more free movement of shoals toward the upper reaches of the basin, especially during the rainy season, when midsized and migratory species can be found, such as the Leporinus aff. friderici. In the Cabeça River, species known as migratory fish were registered only at site number 4 . At this site, the occurrence of some species, such as anostomids Leporinus obtusidens, Schizodon nasutus, Leporinus octofasciatus, Leporinus lacustris and Leporinus aff. friderici, and prochilodontid Prochilodus lineatus, showed the difficulty for upstream fish movement imposed by Altarugio Waterfall. Salminus brasiliensis, belonging to the genus characterized by Sato et al. (2003) as migrant, captured to the upstream of site 4, is the only evidence of large fish toward the upper reaches of the basin. This may have happened in the wettest periods when water can flown fast enough to allow the passage of migratory large fish. So, Altarugio Waterfall may hamper the fish movement but occasionally some individuals or shoals may reach the waterfall upstream stretches.

During sampling at site 4 in January 2011, there was a moment of "spawning" on the Cabeça River, when the shoals moving upstream, became gathered below the Altarugio waterfall. There, 541 individuals of Astyanax altiparanae were collected. On the other hand, upstream from the waterfall (site 3), on the same day, only one individual of this species was captured. The other two sites ( 1 and 2), regardless of the water level or time of spawning, no changes were observed on the abundance of individuals, reinforcing that natural barriers influence the migration of individuals and shoals. Additionally, species with less vagility may be restricted to some river portions because the waterfalls influence. Evidence of this can be reported by the occurrence of Corydoras aeneus, in large shoals above the waterfall Altarugio, and absence of this species at site 4, where only Corydoras flaveolus was recorded. 


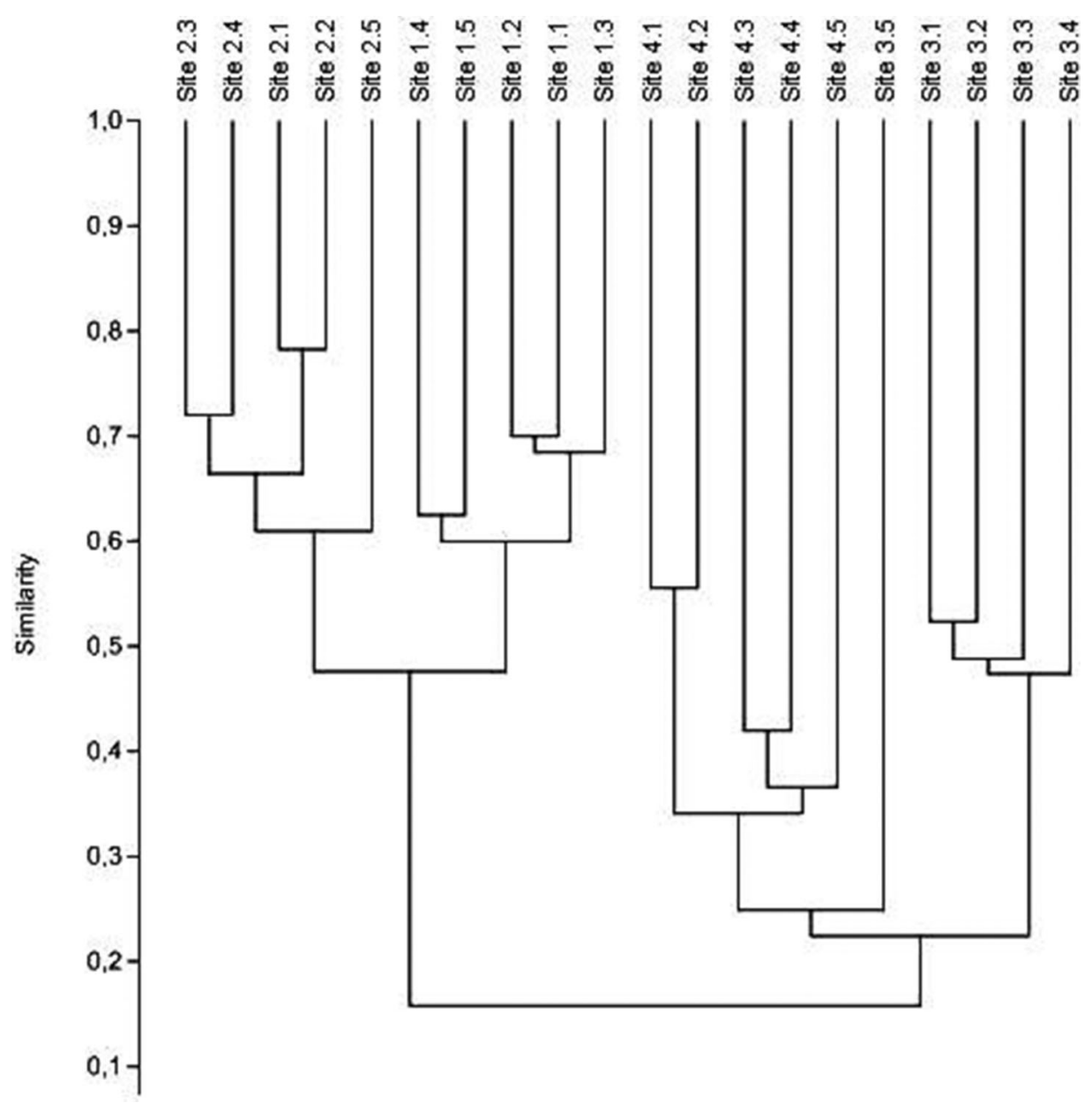

Figure 3. Dendrogram of similarity (Jaccards index) of the samples obtained in each of the four sites at Cabeça River (example: $1^{\text {st }}$ sampling at site 1 $=$ site 1.1 ).

Thus, site 4 proved to be important for regional ichthyofauna. In studies such as of Carmassi et al. (2009), Gomiero \& Braga (2006), Cetra \& Petrere Jr. (2006), in rivers that comprise Corumbataí River basin and, sometimes, Cabeça River, never so many species were found at a single site as found in this research.

The physical features of Cabeça River channel indicate large amount of water at sites near the river's source where it is narrower and relatively deep what leads to higher quantities of exploitable habitat by fish. Discussions of the capacity of an environment support a certain number of species due to its physical conformations can explain the occurrence of many species due to these varieties of habitats. Langeani et al. (2005), who has studied a river in southeastern Brazil has also showed that slower and deepwater environments support more species than the areas of rapids, mainly because their increased complexity and quantity of habitat. The study of Cabeça River revealed different situations from those discussed previously, such as the species-environment relationship at sites 3 and 4 . At site 3, waters are deeper, slower with submerged vegetation (grasses and swamp lilies) as well as submerged vegetal debris and rocks, however this site have had fewer species than the stretches to downstream, which has shallower and fast waters and no submerged vegetation.

The analysis of fish composition and distribution along the Cabeça River showed that small rivers that drain the Cuestas
Basálticas province can furnish shelter to great amount of the native species of the Tietê River basin. The rivers in this area frequently present great altitudinal differences in relatively short extensions, which characterize them to have much rapids and waterfalls. As showed here, in this scenario the fish assemblage distribution along the river may be hardly affected by these geographical accidents. Although the study of fish assemblage in the Cabeça River allows elucidating some of the factors that influence the ichthyofauna, there are still much to investigate for a better understanding in what extension the historical factors represented by waterfalls and geomorphological features and the ecological factors represented by environmental variability and biological interactions affect the structure of fish communities.

\section{Aknowledgments}

Many thanks to Luiz A. C. Bertollo, Heraldo A. Britski e Flávio C. T. Lima by the critic reading and suggestion. We are grateful to the Programa de Pós Graduação em Ecologia e Recursos Naturais (PPG-ERN/UFSCar) by their support for field work during the development of the MSc. Thesis of Rodrigo Torres Cardoso. The Coordenação de Aperfeiçoamento de Pessoal de Nível Superior (CAPES) for the scholarship granted to Rodrigo Torres Cardoso. Luiz A. Joaquim by assisting in field works. Fernando Apone, Elton 
Iniesta and Guiherme Rossi Gorni by helping in laboratory work and thanks to Instituto Chico Mendes de Conservação da Biodiversidade - ICMBio by granting authorization for samples (No. 23363-2).

\section{References}

BALON, E. K. \& STEWART, D. J. 1983. Fish assemblages in a river with unusual gradient (Luongo, Africa-Zaire system), reflections on river zonation, and description of another new species. Environmental Biology of Fishes, 9(3/4): 225-252, doi: http://dx.doi.org/ 10.1007/BF00692373

BENNEMANN, S..T., SILVA-SOUZA, A T. \& ROCHA, G. R. A. 1995. Composición ictiofaunistica en cinco localidades de la cuenca del rio Tibagi, PR - Brasil. Interciencia 20(1): 7-13.

BUCKUP, P. A., MENEZES, N. A., \& GHAZZI, M..S.. 2007. Catálogo das espécies de peixes de água doce do Brasil. Rio de Janeiro, Museu Nacional. 195p.

CARMASSI, A. L., RONDINELI, G. R. \& BRAGA, F. M. S.. 2009. Fish, Passa Cinco stream, Corumbataí river basin, state of São Paulo, Brazil. Check List 5(1): 112-117.

CASATTI, L.. 2005. Fish assemblage structure in a first order stream, southeastern Brazil: longitudinal distribution, seasonality, and microhabitat diversity. Biota Neotropica 5(1): 2-9.

CETRA, M. \& PETRERE JR M. 2006. Fish-assemblage structure of the Corumbatai river basin, São Paulo State, Brazil: characterization and anthropogenic disturbances. Brazilian Journal of Biology 66 (2A): 431-439, doi: http://dx.doi.org/10.1590/S151969842006000300007

DAJOZ, R. 1983. Ecologia geral. 4a ${ }^{\text {a }}$ ed. Petrópolis, Vozes. 472p.

Gomiero, L. M. \& Braga, F. M. S. 2006. Ichthyofauna diversity in a protected area in the State of São Paulo, Southeastern Brazil. Brazilian Journal of Biology 66(1A): 75-83, doi: http://dx.doi.org/ 10.1590/S1519-69842006000100010

JONCK, C. R. \& ARANHA, J. M. R. 2010. Influence of a waterfall over richness and similarity in adjoining pools of an Atlantic Rainforest stream. Acta Limnologica Brasiliensia 22(4): 378-383, doi: http://dx.doi.org/10.4322/actalb.2011.003
KREBS, C. J. 1999. Ecological metodology. $2^{\mathrm{a}}$ ed. New York, Addison Welsey. 620p.

LANGEANI, F., CASATTI, L., GAMEIRO, H..S., BELLUCCODO-CARMO, A. \& ROSSA-FERES, D..C. 2005. Riffle and pool fish communities in a large stream of southeastern Brazil. Neotropical Ichthyology 3(2): 305-311, doi: http://dx.doi.org/10.1590/ S1679-62252005000200009

MAGURRAN, A. E. 1991. Ecological diversity and its measurement. London, Chapman and Hall. 178p.

OLIVEIRA, A. K. \& GARAVELlO, J.. C. 2003. Fish assemblage composition in a tributary of the Mogi Guaçu river basin, southeastern Brazil. Iheringia, Série Zoologia, 93(2): 127-138.

OLIVEIRA, A. K., APONE, F., BIRINDELLI, J. L. O. \& PEREZJUNIOR, O. 2009. Fish, tributaries of middle Rio Mogi Guaçu, upper rio Paraná basin, São Paulo state, Southeastern Brazil. Check List, 5(3): 488-494.

PAVANELLI, C. S. \& CARAMASCHI, E. P. 1997. Composition of the ichthyofauna of two small tributaries of the Paraná River, Porto Rico, Paraná state, Brazil. Ichthyological Explorations of Freshwaters, 8: 23-31.

PEREZ-JUNIOR, O R. \& GARAVELLO, J. C. 2007. Ictiofauna do Ribeirão do Pântano, afluente do Rio Mogi - Guaçu, Bacia do Alto Rio Paraná, São Paulo, Brasil. Iheringia, Série Zoologia, 97(3): 328-335.

SATO, Y., FENERICH-VERANI N., NUÑER A. P O., GODINHO H P. \& VERANI J R. 2003. Padrões reprodutivos de peixes da bacia do São Francisco. In: GODINHO, H. P..; GODINHO, A. L.. (org.). Águas, peixes e pescadores do São Francisco das Minas Gerais. Belo Horizonte: PUC Minas, p. $229-274$

TAVARES, A. C., CHRistofoletTi, A. L. H. \& SANTANA, M. P. C. 2007. Tipos de tempo e feições do escoamento superficial na bacia do rio Corumbataí SP, BRASIL. CLIMEP - Climatologia e Estudos da Paisagem 2(1): 128-147.

VANNOTE, R. L., MINSHALL, G. W., CUMMINS, K. W., SEDELL, J. R. \& CUSHING, C. E. 1980. The river continuum concept. Canadian Journal of Fisheries and Aquatic Sciences 37(1): 130-137, doi: http://dx.doi.org/10.1139/f80-017 